\title{
Viral Hepatitis - The Road Traveled and the Journey Remaining
}

\author{
Ghulam Fareed Malik', Noval Zakaria', Muhammad Ibrahim Majeed $\mathbb{D}^{2}$, Faisal Wasim Ismail' \\ 'Section of Gastroenterology, Department of Medicine, The Aga Khan University, Karachi, Pakistan; ${ }^{2}$ Medical College, The Aga Khan University, \\ Karachi, Pakistan \\ Correspondence: Faisal Wasim Ismail, Section of Gastroenterology, Department of Medicine, The Aga Khan University, Karachi, Pakistan, \\ Tel +92 21-35864528, Fax +92 21-3493005I, Email faisal.ismail@aku.edu
}

\begin{abstract}
Hepatitis is defined as inflammation of the liver and is commonly due to infection with The hepatotropic viruses hepatitis A, B, C, D and E. Hepatitis carries one of the highest disease burdens globally and has caused significant morbidity and mortality among different patient populations. Clinical presentation varies from asymptomatic or acute flu-like illness to acute liver failure or chronic liver disease, characterized by jaundice, hepatomegaly and ascites among many other signs. Eventually, this can lead to fibrosis (cirrhosis) of the liver parenchyma and carries a risk of development into hepatocellular carcinoma. Hepatitis B and $\mathrm{C}$ are most notorious for causing liver cirrhosis; in 2019, an estimated 296 million people worldwide had chronic hepatitis $\mathrm{B}$ infection and 58 million are currently estimated to have chronic hepatitis $\mathrm{C}$, with 1.5 million new infections of both hepatitis $\mathrm{B}$ and $\mathrm{C}$, occurring annually. With the help of latest serological biomarkers and viral nucleic acid amplification tests, it has become rather simple to efficiently screen, diagnose and monitor patients with hepatitis, and to commence with appropriate antiviral treatment. More importantly, the development of vaccinations against some of these viruses has greatly helped to curb the infection rates. Whilst there has been exceptional progress over the years in the management of viral hepatitis, many hurdles still remain which must be addressed in order to proceed towards a hepatitis-free world. This review will shed light on the origin and discovery of the hepatitis viruses, the global epidemiology and clinical symptoms, diagnostic modalities, currently available treatment options, the importance of prevention, and the journey needed to move forward towards the eradication of its global disease burden.
\end{abstract}

Keywords: prevention, diagnosis, management, liver, infection, viral structure

\section{Introduction}

Inflammation of the liver parenchyma in response to viral infections is called viral hepatitis. The hepatotropic viruses including hepatitis A (HAV), hepatitis B (HBV), hepatitis C (HCV), hepatitis D (HDV), and hepatitis E (HEV) make up the majority of such infections. Globally, millions of people are affected by these viruses annually. ${ }^{1}$ The clinical spectrum of disease ranges from asymptomatic to acute hepatitis, acute liver failure, chronic liver disease, and even the development of hepatocellular carcinoma in some proportion of patient. ${ }^{2,3}$

An estimated two billion people have been infected with HBV, with 296 million being chronic carriers of HBV and 58 million being chronic carriers of $\mathrm{HCV}^{4,5}$ In endemic areas, most children are infected with viral hepatitis caused by $\mathrm{HAV}$, at an early age. ${ }^{6}$ The annual death rate by viral hepatitis is 1.4 million, with HBV and HCV being the main culprits, contributing to $90 \%$ of mortalities. ${ }^{1}$

Effective treatment and eradication of viral hepatitis involves a thorough understanding and education, about the origin of these viruses, diagnosis, treatment, and preventative approaches required. This review highlights the global epidemiology, currently available treatments, preventative strategies to combat viral hepatitis, and the journey remaining towards the eradication of its global disease burden. Table 1 summarizes the key points regarding the hepatotropic viruses. 
Table I Comparison of Hepatitis Viruses

\begin{tabular}{|c|c|c|c|c|c|}
\hline & Hepatitis A & Hepatitis B & Hepatitis C & Hepatitis D & Hepatitis E \\
\hline Type of Virus & ssRNA & dsDNA & ssRNA & ssRNA & ssRNA \\
\hline Discovery & 1973 & 1965 & 1989 & 1977 & 1990 \\
\hline Global Prevalence & $\begin{array}{l}\text { - } 1.4 \text { million cases per year }{ }^{106} \\
\text { - Occurs in epidemics }\end{array}$ & 296 million $^{4}$ & 58 million ${ }^{4}$ & 60 million $^{82}$ & 20 million $^{96}$ \\
\hline Transmission & Oro-fecal ${ }^{107}$ & $\begin{array}{l}\text { - Parenteral } \\
\text { - Vertical } \\
\text { - Sexual }\end{array}$ & Parenteral ${ }^{107}$ & Parenteral ${ }^{107}$ & Oro-fecal ${ }^{107}$ \\
\hline Incubation Period & $2-6$ weeks $^{107}$ & $4-26$ weeks $^{107}$ & $2-26$ weeks $^{107}$ & $4-26$ weeks $^{107}$ & $2-8$ weeks $^{107}$ \\
\hline Chronic State & No & Yes & Yes & Yes & $\begin{array}{l}\text { No (may be seen in immunodeficiency } \\
\text { states) }\end{array}$ \\
\hline Clinical Symptoms & $\begin{array}{l}\text { - May be asymptomatic } \\
\text { - Symptoms may include: } \\
\text { - Fever } \\
\text { - Fatigue } \\
\text { - Jaundice } \\
\text { - Nausea } \\
\text { - Vomiting } \\
\text { - Anorexia }\end{array}$ & $\begin{array}{l}\text { - May be asymptomatic } \\
\text { - Symptoms may include: } \\
\text { - Fever } \\
\text { - Fatigue } \\
\text { - Jaundice } \\
\text { - Nausea } \\
\text { - Vomiting } \\
\text { - Anorexia }\end{array}$ & $\begin{array}{l}\text { - Asymptomatic } \\
\text { - Very rarely, symptoms occur in acute } \\
\text { infection }\end{array}$ & $\begin{array}{l}\text { Co-infection: Mirrors } \\
\text { HBV } \\
\text { Super infection: } \\
\text { - May be asymptomatic } \\
\text { - Symptoms may } \\
\text { include: } \\
\text { - Fever } \\
\text { - Fatigue } \\
\text { - Jaundice } \\
\text { - Nausea } \\
\text { - Vomiting } \\
\text { - Anorexia }\end{array}$ & $\begin{array}{l}\text { - May be asymptomatic } \\
\text { - Symptoms may include: } \\
\text { - Fever } \\
\text { - Fatigue } \\
\text { - Jaundice } \\
\text { - Nausea } \\
\text { - Vomiting } \\
\text { - Anorexia }\end{array}$ \\
\hline $\begin{array}{l}\text { Laboratory } \\
\text { Diagnosis }\end{array}$ & Anti-HAV IgM antibodies ${ }^{107}$ & $\begin{array}{l}\text { - } \mathrm{HBsAg} \text { detection }{ }^{107} \\
\text { - HBcAg antibodies } \\
\text { - HBV DNA PCR }\end{array}$ & $\begin{array}{l}\text { - Anti-HCV antibodies } 107 \\
\text { - HCV RNA PCR }\end{array}$ & $\begin{array}{l}\cdot \text { Anti-HDV } \\
\text { antibodies }{ }^{107} \\
\cdot \text { HDV RNA PCR }\end{array}$ & $\begin{array}{l}\text { - Anti-HEV antibodies }{ }^{107} \\
\text { - HEV RNA PCR }\end{array}$ \\
\hline Treatment & Supportive & $\begin{array}{l}\text { - Supportive } \\
\text { - Anti-viral therapy }\end{array}$ & $\begin{array}{l}\text { - Supportive } \\
\text { - Anti-viral therapy }\end{array}$ & $\begin{array}{l}\text { - Supportive } \\
\text { - Anti-viral therapy }\end{array}$ & Supportive \\
\hline Prevention & $\begin{array}{l}\text { - HAV Vaccine } \\
\text { - Improving sanitation } \\
\text { - Provision of clean drinking } \\
\text { water } \\
\text { - Appropriate disposal of sewage } \\
\text { - Educating the public }\end{array}$ & $\begin{array}{l}\text { - HBV Vaccine } \\
\text { - Screening } \\
\text { - Educating the public }\end{array}$ & $\begin{array}{l}\text { - Screening } \\
\text { - Educating the public }\end{array}$ & $\begin{array}{l}\text { - HBV Vaccine } \\
\text { - Educating the public }\end{array}$ & $\begin{array}{l}\text { - HEV Vaccine } \\
\text { - Improving sanitation } \\
\text { - Provision of clean drinking water } \\
\text { - Appropriate disposal of sewage } \\
\text { - Educating the public }\end{array}$ \\
\hline
\end{tabular}

Abbreviations: ssRNA, single stranded RNA; dsDNA, double stranded DNA; HAV, hepatitis A virus; $H B V$, hepatitis $B$ virus; $H C V$, hepatitis $C$ virus; $H D V$, hepatitis D virus; $H E V$, hepatitis $E$ virus; $H B s A g$, hepatitis $B$ surface antigen; $\mathrm{HBcAg}$, hepatitis B core antigen; PCR, polymerase chain reaction; IgM, immunoglobulin M; IgG, immunoglobulin G. 


\section{Hepatitis A Virus (HAV) \\ Discovery}

First isolated in 1973, HAV is a small, $27 \mathrm{~nm}$ un-enveloped symmetrical RNA virus, initially classified in the genus of Enteroviruses belonging to the Picornaviridae family. ${ }^{7-9}$ After the entire nucleotide sequence of the viral genome was determined, HAV was reclassified as a Hepatovirus. ${ }^{10}$

\section{Epidemiology and Clinical Symptoms}

HAV is contracted via fecal-oral transmission by using contaminated food and water. Millions of individuals live in highrisk conditions to contract HAV viral hepatitis, which is especially true in developing countries. Young children that get HAV may be asymptomatic. Older children, adolescents, and adults present with fatigue, fever, and/or jaundice, which lasts for a few weeks before resolution. ${ }^{11}$ This subset is also at risk of developing acute liver failure and subsequent death. Globally, the incidence of HAV is reducing with better social awareness about sanitation and hygiene. ${ }^{12}$ However, the incidence and prevalence of HAV highly varies from country to country, with socioeconomic status being the major determinant of the population's exposure to HAV and its complications.

The likelihood of developing symptoms increases up to $40-50 \%$ in the age bracket of 6-14 years and $70-80 \%$ in older age groups. ${ }^{10}$ Due to virus exposure, host immunity does develop Against HAV, providing long-term immunity against HAV. ${ }^{13}$

The main risk factor of HAV transmission in such a population relates to individuals traveling to a country highly endemic with HAV. Sexually active homosexuals, military personnel, sewage workers, and intravenous drug abusers (IVDA) are also high-risk groups. ${ }^{14}$ A major previously noted risk factor is access to sanitary water sources utilized for toilette purposes, hand washing, drinking water, and food preparation. ${ }^{15,16}$

After HAV infection, the virus enters into the host bloodstream through the intestine and targets the liver parenchyma, resulting in focal activation of sinusoidal lining and hepatic necrosis with subsequent elevations of aminotransferases. ${ }^{17}$ During the incubation period, viral replication occurs at its peak which is then excreted into the bile with maximum viral shedding via feces, whilst the host is asymptomatic. ${ }^{18}$ It may progress to the icteric phase (lasting up to 2 months or rarely, with a relapsing and remitting course of 6 months) or non-icteric hepatitis. IgM antibodies are produced within one week of viral infection. ${ }^{19,20}$ Levels begin to plateau in 2 months during which long-term protective IgG antibodies are formed that persist for many years. ${ }^{21}$

\section{Diagnostic Tests}

Various methods for testing HAV include immune electron microscopy, immune adherence heme agglutination, and radioimmunoassay. ${ }^{7,22}$ Of these, the most commonly used method includes immune adherence immunoassay. Detection of serum IgM antibodies against Hepatitis A is the most commonly used diagnostic test whereas, hepatitis A PCR testing is reserved for a limited number of patients including the immunocompromised. ${ }^{23,24}$

\section{Management and Prevention}

Treatment is symptomatic for the majority of patients, with avoidance of hepatotoxic drugs during the period of active inflammation within the liver. Rarely it can lead to acute liver failure requiring a liver transplant. As HAV is one of the leading causes of viral hepatitis, it necessitates the need to provide protective passive immunity against HAV, in the form of administration of pooled normal human immunoglobulin, at a dose of $100 \mathrm{IU} / \mathrm{mL}$, given intramuscularly. ${ }^{25,26}$ Administration provides immunity for up to 3-5 months. In the United States, the two available vaccines are inactivated HAV vaccine HAVRIX (GlaxoSmithKline Biological) and VAQTA (Merck \& Company), capable of triggering an immune response and HAV antibody production. ${ }^{27}$

\section{Way Forward}

HAV vaccine is not freely available in third world countries where this disease is endemic. While vaccination provides protection efficiently, clean sanitation practices, provision of clean drinking water, and appropriate disposal of human 
waste will ensure eradication of viral spread. Increased awareness, improvement in sanitation, and improved socioeconomic conditions with access to vaccination are important strategies for the future in limiting infection.

\section{Hepatitis B Virus (HBV)}

\section{Discovery}

Hepatitis B was first discovered in 1965 by Dr. Baruch Blumberg.

Hepatitis B is part of the genus Orthohepanaviridae, belonging to the Hepadnaviridae family. The virus is an enveloped, $42 \mathrm{~nm}$ particle identified as the Dane particle, which was first seen via electron microscopy. ${ }^{28}$

\section{Epidemiology and Pathogenesis}

Globally, there are an estimated 296 million cases of chronic hepatitis B with an annual death rate of one million due to hepatitis B-related complications. ${ }^{29}$ Hepatitis B can present as acute hepatitis or acute liver failure on one hand whereas, it can remain asymptomatic and progress to become a chronic liver disease, potentially even leading to hepatocellular carcinoma in certain patients. ${ }^{3}$

The journey of the HBV virus into the host cell; the entry, viral replication, and assembly all provide target sites for new drug therapies.

\section{Viral Structure and Encoding}

Hepatitis B is a partially double-stranded DNA virus. Its DNA exists in a relaxed, circular, partially double-stranded configuration. It contains four open reading frames, and the morphology allows multiple genes to overlap to use the same DNA for different viral proteins.

The four genes include core, surface antigen (HBsAg), X, and polymerase gene. Portion X produced by gene $\mathrm{X}$ is responsible for transactivation and possibly hepatocellular carcinoma. Hepatitis B surface antigen (HBsAg) plays an important role in viral entry, hyposensitization of the adaptive immune system, and is an important parameter in monitoring response to treatment (HBsAg loss). The core protein formed by gene $\mathrm{C}$ is a part of the nucleocapsid structure of the virus. Along with its structural contribution, the core proteins trigger the formation of hepatitis B core antibodies. ${ }^{30}$

\section{Diagnostic Tests}

Serological assays are utilized for the diagnosis of hepatitis B virus infection. Hepatitis B surface antigen (HBsAg) is the most common screening test for hepatitis B, whereas hepatitis B surface antibodies (HBsAb) are used for assessing immunity post recovery or after vaccination.

Hepatitis B core ( $\mathrm{HBc}$ ) IgM and Hepatitis B core IgG are used to distinguished acute and chronic infections, respectively. Hepatitis B e Antigen ( $\mathrm{HBeAg}$ ) is a marker of infectivity and usually appears early during the disease when viral replication is at its peak. In self-limiting causes or after treatment, it can be replaced by antibodies that are Anti-Hepatitis $\mathrm{B}$ e antibodies (HBeAb). When there is pre-core mutation, patients will be Hepatitis e Antigen negative whilst suffering chronic hepatitis B. Viremia in hepatitis B is assessed by polymerase chain reaction (PCR) which detects hepatitis B DNA levels. ${ }^{31}$

Qualitative and quantitative tests for HBV DNA in serum have been developed to assess HBV replication. Currently, most HBV DNA assays use real-time PCR techniques, report results in international units $/ \mathrm{mL}$, have a lower limit of detection (around 10 to 20 international units $/ \mathrm{mL}$ ) and a range of linearity up to $8 \log (10)$ international units $/ \mathrm{mL}^{32}$

The main challenge in HBV diagnosis is to identify and test people at risk in the community, such as sexual workers and drug addicts, and patients with occult HBV. This is a condition characterized by the absence of HBsAg in serum, and presence of HBV DNA by PCR in serum and in the liver. ${ }^{33}$

Occult HBV has been reported among many high risk groups, including blood donors, liver transplant recipients, patients co-infected with hepatitis $\mathrm{C}$ virus/human immunodeficiency virus and patients undergoing immunosuppressive therapy. ${ }^{34}$ 
A high index of suspicion is required for its diagnosis and it is recommended to screen with HBV DNA by real-time PCR periodically, in high risk groups to diagnose and treat these patients in a timely manner. ${ }^{35}$

\section{Nomenclature of HBV Infection}

The interplay of viral replication versus the host immune response against the virus dictates which individual harbors a chronic infection and which would go on to develop chronic hepatitis (CHB). The new nomenclature describes chronic HBV infection in two characteristic forms: infection (with no inflammation) versus hepatitis (inflammation). ${ }^{36}$

The HBV chronic infection in human hosts has been described in five phases. The five phases of HBV infection include: 1. Patients with HBeAg positivity and high tigers of HBV DNA. Also known as the immune tolerant phase, this phase usually lasts up to many years, with most patients in this phase having had acquired HBV infection perinatally. An important concept is that $\mathrm{HBeAg}$, as previously stated, causes reduced sensitivity of the adaptive cytotoxic T (CD8 cells) and $\mathrm{T}$ helper cells (CD4) cells to identify and target HBV infection. ${ }^{37}$ Thus, these patients have normal to an upper limit of the normal level of alanine transaminase (ALT). This implies that even in the presence of a high viral load, there is little parenchymal inflammation and/or necrosis. 2. Phase two defines HBeAg positive chronic hepatitis, previously the immune clearance phase. This is associated with a high HBV DNA viral load and raised ALT, reflecting moderate to severe liver inflammation, necrosis, and accelerated healing with fibrosis. 3. Phase three is $\mathrm{HBeAg}$ negative chronic HBV infection with low to normal levels of HBV viral load, normal ALT, and positive HBeAb. 4. HBeAg negative chronic hepatitis is a reactivation of the inactive state that may be triggered by a superimposed viral infection, medications, or toxic injury. There is moderate to high HBV viral load, and elevated ALT which define phase four of hepatitis B. This is associated with histological evidence of fibrosis and liver and ongoing necro-inflammation, with low chances of spontaneous disease remission. The final phase five is characterized by negative HBsAg, positive anti-HBs, positive anti-HBc, normal ALT levels, and low to undetectable levels of HBV DNA. This phase is called occult HBV infection. ${ }^{38,39}$

\section{Management and Prevention}

Interferon-Alpha (IFN-A) and Pegylated Interferon (PEG IFN)

The first drug approved for the treatment of hepatitis B was interferon-a (IFN-A). Its use in treatment for Hepatitis B dates back to 1976. Interferons are essentially cytokines secreted by dendritic cells in response to parasitic, bacterial, and viral exposure with a low molecular weight of $15-30 \mathrm{kDa}$, having anti-viral characteristics. Its main mechanism of action is triggering cellular mediated immunity. At a nuclear level, IFN-A interferes with transcription mediated by host RNA polymerase on the cccDNA.

Pegylated interferon-alpha was introduced in 2001, where the active drug is conjugated with polyethylene glycol molecules that prolong its half-life, allowing only weekly administrations. ${ }^{40-42}$ Under the current guidelines, Peg IFN-A is recommended in patients who have $\mathrm{HBeAg}$ positive/negative $\mathrm{CHB}$ without cirrhosis or selected few patients with cirrhosis but no portal hypertension. The duration of treatment is 12 months (48 weeks). Patients with decompensated liver disease may develop flares of hepatitis, thereby making Peg IFN-A a contraindication to therapy in decompensated cirrhosis. $^{43}$

\section{Nucleoside/Nucleotide Analogs}

The nucleoside analogs are the approved treatment options for CHB patients. Lamivudine, adefovir dipivoxil, and telbivudine were previously recommended but are now replaced by a high-barrier to resistance drugs, like Tenofovir disoproxil fumarate, Tenofovir alafenamide, and Entecavir.

\section{Entecavir}

Entecavir is a novel deoxyguanosine analog that has antiviral activity against HBV. It is administered at a dose of $0.5 \mathrm{mg}$ once a day. Upon entry into the host cell, the drug gets phosphorylated by host kinases to its active moiety. Its mechanism of action is halting HBV DNA elongation by the addition of few additional nucleotides. 
In $\mathrm{HBe} A g$ positive $\mathrm{HBV}$ infection, ETV has a $20 \%$ efficacy rate for seroconversion of $\mathrm{HBeAg}$ in subjects who are NA naïve whereas in $\mathrm{HBeAg}$ negative patients, HBV DNA undetectable rate is $90 \%$ after treatment with $\mathrm{ETV}^{44}$

\section{Tenofovir Disoproxil Fumarate and Tenofovir Alafenamide}

Tenofovir, an acyclic nucleoside phosphonate is an analog of adenosine 5 monophosphate. It hinders the activity of HBV reverse transcriptase by competing with its natural analog, thus terminating HBV genome replication. There are two available formulations; tenofovir disoproxil fumarate and tenofovir alafenamide. As it is not metabolized in the liver, tenofovir can be given in subjects with deranged liver function.

Recent studies have concluded that tenofovir disoproxil fumarate, at a dose of $300 \mathrm{mg}$ OD, is associated with a higher risk of chronic kidney-related disease, proteinuria, osteoporosis, and bone fractures. ${ }^{45}$ To overcome its adversities, a new prodrug- tenofovir alafenamide, has been developed at a dose of $25 \mathrm{mg}$ once daily. Pharmacodynamics studies have proven that the low concentrations of tenofovir provided by the tenofovir alafenamide formulation are linked to lesser adverse effects that are seen in the original formulation, with similar efficacy, but better tolerance. $^{45,46}$

\section{Treatment Parameters}

As described above, hepatitis B exists in 5 recognized phases.

Indication for treatment includes reducing necro-inflammation and subsequent progression to fibrosis, reducing chances of developing hepatocellular carcinoma and preventing decompensation. ${ }^{47}$ All patients with an HBV viral load of $>2000 \mathrm{IU} / \mathrm{mL}$, alanine transaminase (ALT) greater than the upper limit of normal, and evidence of necroinflammation on non-invasive fibrosis assessments, or based on histological evidence, warrant treatment. ${ }^{42}$ Additionally, patients with a high viral load of $>20,000 \mathrm{IU} / \mathrm{mL}$, with ALT 2 times the upper limit of normal, regardless of the level of necro-inflammation require treatment. ${ }^{33,48}$ Another indication is cirrhosis. Patients with early compensated cirrhosis can be treated with Peg-INF but with decompensation, high barrier resistance agents like TDF/TAF are preferred.

\section{HBV Vaccination}

The most commonly used vaccine is the recombinant hepatitis B vaccines using yeast-derived hepatitis B surface antigen. ${ }^{49}$ The recommended regimes are 0,1 , and 6 months. Accelerated doses can be given in 0,1 , and 3 months, with a booster shot at 12 months. ${ }^{50,51}$

In November 2017, a new recombinant hepatitis B vaccine designated as HepB-CpG, with a trade name of HeplisavB received approval for use in adults 18 years of age and older. This vaccine consists of recombinant HBsAg with a novel immunostimulatory adjuvant. ${ }^{52}$

The vaccine is administered as two intramuscular doses given one month apart. The accelerated regimen used with this vaccine has the advantage of providing more rapid immune protection and increases the likelihood of completing the vaccine series. However, data on the use of this vaccine in children, pregnant women, and patients receiving hemodialysis are limited, and this vaccine is not approved for use in these populations. ${ }^{53,54}$

For most persons, routine postvaccination testing to document anti-HBs seroconversion is unnecessary, since the recombinant hepatitis B vaccines generally have a response rate of greater than $90 \%{ }^{55}$

The response rate is lower in obese individuals, smokers, men, and significantly lower in patients with diabetes, cirrhosis, chronic renal failure, organ transplant recipients, and immunosuppressed patients. ${ }^{56}$

Routine postvaccination testing is only indicated in this select group of people, or in those with ongoing risk exposure for example, health care workers and sex partners of HBsAg-positive patients. For such patients, a booster dose is indicated if anti-HBs declines to less than 10 milli-international units $/ \mathrm{mL}$. A positive immune response to vaccination is defined as the development of hepatitis B surface antibody (anti-HBs) titers greater than 10 milli-international units/ $\mathrm{mL} .^{57}$

When postvaccination testing after the initial series is indicated, it should be performed one to two months after the last dose. Non-responders to the initial series should complete a second vaccine series. ${ }^{58}$ 
Individuals who fail to respond after a second series are unlikely to benefit from further vaccination, and should be tested for undiagnosed chronic HBV infection. ${ }^{57}$

A new generation of recombinant HBV vaccines expressed in mammalian cells containing Pre-S/S epitopes has been developed in several countries. These are especially useful in high-risk groups and non-responders, as opposed to conventional HBV vaccines. ${ }^{59}$ These have been shown to be highly immunogenic, and induce faster and higher seroprotection rates against HBV with higher anti-HBs levels compared to conventional yeast-derived vaccines. There is also some evidence to suggest that such Pre-S/S vaccines might be efficacious not only for prevention, but also for treatment of persistent HBV infection. ${ }^{60}$

\section{Way Forward}

Various emerging drugs like host targeting agents and direct-acting antivirals are under investigation as a potential source of treating hepatitis B virus infection by affecting cccDNA.

\section{Core Protein Assembly Modulators}

These are a new class of antiviral agents that inhibit the assembly of core proteins around the viral genome to form the nucleocapsid. The assembly of core proteins is inhibited so viral replication cannot occur. There is thus, the production of empty capsids. ${ }^{61,62}$

ABI-H0731 is an investigational inhibitor of the HBV core protein. In randomized, placebo-controlled Phase 1 and 2 studies, the drug has been effective in viral suppression in a dose dependent manner.

GSK3228836 is an antisense oligonucleotide targeting HBV RNA. It is currently under investigation in an open-label single-arm exploratory study in patients with $\mathrm{HBeAg}$ negative CHB.

\section{Entry Inhibitors}

HBV and HDV gain entry into hepatocytes via NTCP receptors. Bulevirtide (Myrcludex-B) is a novel entry inhibitor. Studies conducted have shown a decline in HBV viral load, however, the agent has minimal effect on hepatocytes already harboring the virus making it less efficacious for monotherapy. Thus, it is considered to be a synergistic agent with other antiviral medications.

\section{cccDNA Silencing}

After the HBV virus gains entry into hepatocytes, the genome enters into the nucleus in its relaxed circular DNA form, where it is subsequently converted to covalently-closed circular DNA form (cccDNA). Zinc finger nucleases are known to inhibit this conversion, epigenetically modify cccDNA, and degrade it. It remains an attractive upcoming class of antiviral due to its capability of reducing cccDNA. ${ }^{63}$

VIR-2218 is an investigational GalNAc-conjugated small interfering ribonucleic acid (siRNA), which is capable of targeting region $\mathrm{X}$ of the HBV genome, thus halting transcription from the integrated HBV DNA and the cccDNA. ${ }^{63}$

PreS1-polypeptide vaccination presents strong immunogenicity for both B-cell and T-cell responses. Studies in mice models demonstrated that the new anti-PreS1 is capable of clearing HBV DNA in carrier mice and prevents infection of healthy cells.

Thus, the future may bring many Medicines that may enable a cure for HBV.

\section{Hepatitis C Virus \\ Discovery}

The Center for Disease Control and California Biotechnology Company had first discovered the non-A non-B hepatitis (NANBH) later named Hepatitis C. Its genome was identified soon after as a single-stranded RNA. ${ }^{64}$

\section{Epidemiology and Pathogenesis}

HCV binds to the host cell receptors and enters the cell via clathrin-mediated endocytosis. The viral genome is liberated from its envelope during endocytosis and the single-stranded positive polarity RNA enters into the cytoplasm where the 
RNA acts as a template for protein translation. NS3, NS4, NS5A and NS5B are nonstructural proteins which are important sites for therapeutic actions of the new direct-acting antiviral drugs. ${ }^{65}$

The World Health Organization had created a Global Hepatitis Strategy in 2015 that aimed to eliminate viral hepatitis by 2030 with a reduction in incidence by $90 \%$, and a $65 \%$ reduction in mortality. However, even with the advent of new direct-acting antivirals (DAAs), developing countries face little chance of reaching the goals of the Global Hepatitis strategy by 2030 , as only a few countries have granted coverage for DAAs ${ }^{66,67}$ Egypt is the only developing country of the 9 countries, that are aimed to achieve this target by 2030 .

Furthermore, with the use of injectable drugs on the rise, especially amongst the young population, the prevalence of $\mathrm{HCV}$ is further increasing. The majority of these injectable drug users remain undiagnosed and represent a major proportion of the high-risk individuals, who continue to spread infection and contribute to the global disease burden. ${ }^{68,69}$

\section{Diagnostic Tests}

Immunoassay for antibodies against $\mathrm{HCV}$ (anti-HCV) is the test of choice for diagnosis and screening of HCV patients. Anti-HCV positivity suggests ongoing or past infection. The next step for confirming the diagnosis is HCV RNA testing via polymerase chain reaction (PCR). Previously, genotyping was important but now it is not necessary in most cases after the advent of pan-genotypic DAAs.

It is important however, to note that there is an estimated 56-70 day "window period", in which antibody titers may not be detectable. To overcome this hurdle and detect infection earlier on, HCV core antigen (HCVcAg) quantification assay has also been developed as a marker of infection, which has a high clinical sensitivity and is relatively inexpensive. However, it's use is limited as only few research centres have it available and HCV RNA detection remains the goldstandard in confirming HCV infection in clinical practice. ${ }^{70,71}$

\section{Management and Prevention}

The main goal of HCV therapy is to achieve undetectable HCV-RNA in serum. Initial management regimes included Peg-INF and Ribavirin. However, treatment was characterized by poor success rates, and adverse effects. ${ }^{72}$

In 2015, multiple direct-acting antivirals emerged that revolutionized HCV treatment. There are four classes of drugs that are classified according to their target protein. These include NS3/4a protease inhibitors, NS5B nucleoside polymerase inhibitors, NS5B non-nucleoside polymerase inhibitors (NNPIs), and NS5A inhibitors. ${ }^{73}$

$\mathrm{NS} 3 / 4 \mathrm{a}$ are proteases involved in post-translational modifications of the newly synthesized polyprotein. ${ }^{74}$ NS5A plays a role in the organization of the replication complex and assembling the virion before its cellular exit. ${ }^{75}$ Nonstructural protein 5B (NS5B) is a viral protein that is an RNA-dependent RNA polymerase, thus essential for HCV viral replication. ${ }^{76}$ Sofosbuvir is the first NS5B nucleoside polymerase inhibitor available. Other newer agents are Glecaprevir, Grazoprevir, and Paritaprevir. NS5A inhibitors include Pibrentasvir and Elbasvir. ${ }^{77}$

Other NS5A's are used in combination with Sofosbuvir, including Sofosbuvir and Velpatasvir, and Sofosbuvir and Ledipasvir. Both these combinations can be given in cirrhosis regardless of severity, but due to the excreted metabolite of Sofosbuvir that is GS 331007, their use is limited in patients with an eGFR $<300^{78}$

The development of pan-genotypic combination DAAs have revolutionized HCV treatment - the need for pegylated interferon has been removed and the use of ribavirin and need for virological testing services, have considerably reduced. Whilst these combination therapies have simplified treatment to a great deal, some genotypes (such as genotype 3), still require adjustment in the selection of agents, duration of treatment and the need for adjuvant ribavirin. It is therefore, important for national health authorities to select specific combination therapies, based on the regional genotypic prevalence to overcome the aforementioned constraints, in addition to some baseline resistance polymorphisms. Furthermore, these treatment regimens are relatively costly making widespread accessibility and affordability in developing countries limited, which poses yet another constraint. ${ }^{79}$

Whilst pharmacological therapy remains the definitive management, it is also imperative to educate the population about the transmission of HCV infection, as a lack of awareness has most commonly been associated with spread of disease. High-risk individuals should be preferentially screened, and latest anti-HCV medications should be made easily available. $^{68,69}$ 


\section{Way Forward}

Pan-genotypic DDAs are a treatment of choice for HCV with excellent efficacy. Active screening and treatment along with educating people regarding preventive measures are the need of the hour, especially for third world countries. These measures will help to achieve the WHO aims of eliminating viral hepatitis by 2030 .

\section{Hepatitis D Virus (HDV) \\ Discovery}

HDV was first discovered by Rizetto, in 1977 and it is a $30-35 \mathrm{~nm}$, circular, and covalently-closed single-stranded RNA virus. $^{80,81}$

\section{Epidemiology and Pathogenesis}

An estimated 60 million people are infected with HDV globally. ${ }^{82}$ It is a defective virus that does not synthesize its envelope proteins, thus requiring the HBV surface antigen in the host cells to complete its replication. HDV is capable of entering into hepatocytes and replicating its genome. It is however, unable to release its virions without the simultaneous co-infection with $\mathrm{HBV}^{83}$

Simultaneous HDV and HBV co-infection manifests as acute hepatitis, with fever, nausea, vomiting, and jaundice. ${ }^{84}$ There is a biphasic increase in aminotransferase, with an initial peak due to HBV replication and the second peak due to HDV viremia. ${ }^{85}$ Another manifestation is HDV superinfection in an individual who is chronically infected with HBV. In both scenarios, there lies a risk of acute liver failure. ${ }^{86}$

\section{Diagnostic Tests}

HDV screening is recommended in individuals who are chronically infected with HBV. Anti-HDV antibodies can be detected with enzyme-linked immunosorbent assays (ELISA) or Rapid immunosorbent assays (RIA), and are available as IgM and IgG antibodies for the diagnosis of acute or chronic infections, respectively. The test, however, may not be positive in the initial days-weeks of the infection. HDV RT-PCR remains the confirmatory test of choice. This distinguishes an ongoing infection from past infections. ${ }^{87,88}$

\section{Management and Prevention}

The goals of therapy for a dual HDV and HBV are similar to the endpoint of treatment for HBV; to achieve a virological response with undetectable HDV and HBV PCR, with a sustained virological response up to 24 weeks post-treatment. However, in the case of CHD, relapse rates remain as high as $50 \%$ in patients treated with PEG-IFN.

PEG-IFN remains the only recommended treatment for HDV, with a meta-analysis reporting a $25 \%$ sustained suppression of HDV RNA 24 weeks post-treatment. The recommended duration of therapy is 48 weeks. ${ }^{89}$

Nucleoside/Nucleotide analogs have not proven beneficial in CHD infections, thus not recommended. Preventive measures and early screening of hepatitis B patients for hepatitis D are important as the only recommended treatment is PEG-IFN alpha, which can be given predominantly in non-cirrhotic patients only. ${ }^{83}$

\section{Way Forward}

Drugs in the development phase include agents that inhibit crucial steps for viral entry and assembly in the host cells. Myrcludex B, a myristoylated lipopeptide has a similar N terminal amino acid structure to L-HBsAg, thus is capable of binding to NCTP and preventing viral entry into the cell. ${ }^{90}$

Lonafarnib is a farnesylation inhibitor. It prevents farnesylation of L-HDAg, thus inhibiting the assembly of HDV RNP with HBsAg. Multiple studies have shown a reduction in HDV RNA levels on sorafenib, combined with PEG-IFN /Ritonavir, but relapse is seen 8 weeks post-treatment. ${ }^{91,92}$

Various ongoing trials are combing interferon lambda with lonafarnib as well. Nucleic acid polymers and drugs like ezetimibe are under investigation for the treatment of chronic hepatitis D. ${ }^{93}$ 
HBV vaccines work to protect against HBV and HDV, by reducing the number of individuals at risk of HBV. Currently, no encouraging results have been demonstrated for vaccines to protect against HDV in HBV-infected individuals.

\section{Hepatitis E (HEV) \\ Discovery}

In 1990, Reyes et al successfully sequenced the Hepatitis E virus genome. ${ }^{94} \mathrm{HEV}$ is a $7.2 \mathrm{kB}$ single-stranded positive polarity RNA virus belonging to the Hepeviridae family. ${ }^{95}$

\section{Epidemiology and Pathogenesis}

Globally hepatitis $\mathrm{E}$ is a growing cause of concern as it is one of the leading causes of viral hepatitis. There are at least 4 genotypes that can infect humans. The annual number of recorded cases has been a staggering 20 million with 3.3 million symptomatic cases and a death toll of 60,000 reported. ${ }^{96} \mathrm{HEV}$ has also remained one of the main factors in causing maternal and fetal mortality during pregnancy, and around $15-60 \%$ of acute hepatitis $E$ infection progresses to acute liver failure in pregnant patients in developing countries. ${ }^{97,98}$ In Iran, epidemiological studies have reported seropositivity between 3.6 to $7.4 \%$ amongst pregnant women, depending upon the geographical location and the level of hygiene in each area. ${ }^{99}$

The main source of transmission is the fecal-oral route through contaminated water sources or undercooked meat.

Usually, hepatitis resulting from HEV has a self-limiting course, with an incubation period of $2-8$ weeks, and prodromal symptoms of jaundice, fatigue, nausea, and vomiting. However, chronicity resulting in liver damage and cirrhosis has been seen in elderly, immunocompromised individuals, and/or HIV-positive individuals. ${ }^{100}$

An important breakthrough in understanding the variations in HEV clinical manifestations is the genomic mutations. The HEV genome is a capped virus that attains this character due to the presence of ORF-1 encoded methyltransferase. A multitude of studies have demonstrated that a mutation in the ORF-1 region for methyltransferase is present in patients infected with HEV causing acute viral hepatitis or acute liver failure. Paradoxically, single point mutation of H105R resulted in lower viremia, thus being a possible target of therapy. A G1634R point mutation in RdRp in immunocompromised individuals correlated with higher viremia and resistance to Ribavirin treatment. ${ }^{101}$

\section{Diagnostic Tests}

Detection of Serum IgM antibodies against Hepatitis E is the most commonly used diagnostic test whereas, Hepatitis E PCR testing is reserved for a limited number of patients including the elderly and immunocompromised. ${ }^{102}$

\section{Management and Prevention}

Symptomatic treatment for the majority of patients and avoidance of hepatotoxic drugs will lead to full recovery but during pregnancy, chances of acute liver failure are more and close monitoring is mandatory for such patients. Rarely genotypes 3 and 4 can lead to chronic infection especially in the elderly and immunocompromised individuals. Ribavirin has a role in the treatment of hepatitis $\mathrm{E}$ in immunocompromised patients. ${ }^{103,104}$

\section{Way Forward}

HEV vaccine is not readily available in the world but Hecolin is a commercially available approved hepatitis E vaccine in China with promising control of epidemic and sporadic hepatitis E cases. The way forward will be similar to HAV as the mode of spread is the same. Improving sanitation, educating the public, providing HEV vaccination and perhaps even including this in pediatric vaccination programs, will help us to control and eradicate this disease. ${ }^{105}$

\section{Conclusion}

Viral hepatitis continues to harbor a significant global health burden and a fundamental understanding of its structural, epidemiological and clinical features are imperative in the fight to eradicate the disease. Efficient and risk-based screening programs, combined with advanced diagnostic modalities allow prompt recognition of infection and early 
initiation of treatment, thereby controlling disease transmission. With continuous progress in anti-viral therapies available, the challenge of tackling this ubiquitous infection has greatly reduced however, efforts towards prevention such as vaccination, remain the first-step and are of paramount importance. It is through these key measures, and the establishment of global health policies that sanction widespread accessibility to the latest diagnostic tests and therapeutic drugs, that we can achieve our goal of a hepatitis-free world.

\section{Disclosure}

The authors report no conflicts of interest in this work.

\section{References}

1. Jefferies M, Rauff B, Rashid H, Lam T, Rafiq S. Update on global epidemiology of viral hepatitis and preventive strategies. World J Clin Cases. 2018;6(13):589-599. doi:10.12998/wjcc.v6.i13.589

2. Lin J, Wu J-F, Zhang Q, Zhang H-W, Cao G-W. Virus-related liver cirrhosis: molecular basis and therapeutic options. World J Gastroenterol. 2014;20(21):6457-6469. doi:10.3748/wjg.v20.i21.6457

3. Ringelhan M, McKeating JA, Protzer U. Viral hepatitis and liver cancer. Philos Trans R Soc Lond B Biol Sci. 2017;372(1732):20160274. doi: $10.1098 /$ rstb.2016.0274

4. World Health Organization. Global progress report on HIV, viral hepatitis and sexually transmitted infections; 2021.

5. Schilsky ML. Hepatitis B “360”. Transplant Proc. 2013;45(3):982-985. doi:10.1016/j.transproceed.2013.02.099

6. Jacobsen KH, Wiersma ST. Hepatitis A virus seroprevalence by age and world region, 1990 and 2005. Vaccine. 2010;28(41):6653-6657. doi:10.1016/j.vaccine.2010.08.037

7. Feinstone SM, Kapikian AZ, Purceli RH. Hepatitis A: detection by immune electron microscopy of a virus-like antigen associated with acute illness. Science. 1973;182(4116):1026-1028. doi:10.1126/science.182.4116.1026

8. Cuthbert JA. Hepatitis A: old and new. Clin Microbiol Rev. 2001;14(1):38-58. doi:10.1128/CMR.14.1.38-58.2001

9. Saberifiroozi M. Prevention of hepatitis A infection. Hepat Mon. 2005;5:19-27.

10. Zuckerman AJ. Hepatitis Viruses. In: Baron S, editor. Medical Microbiology. 4th edition. Galveston (TX): University of Texas Medical Branch at Galveston; 1996. Chapter 70

11. Franco E, Meleleo C, Serino L, Sorbara D, Zaratti L. Hepatitis A: epidemiology and prevention in developing countries. World J Hepatol. 2012;4(3):68-73. doi:10.4254/wjh.v4.i3.68

12. Agrawal A, Singh S, Kolhapure S, Hoet B, Arankalle V, Mitra M. Increasing burden of hepatitis A in adolescents and adults and the need for long-term protection: a review from the Indian subcontinent. Infect Dis Ther. 2019;8(4):483-497. doi:10.1007/s40121-019-00270-9

13. Ruiz-Gomez J, Bustamante-Calvillo ME. Hepatitis A antibodies: prevalence and persistence in a group of Mexican children. Am J Epidemiol. 1985;121(1):116-119. doi:10.1093/oxfordjournals.aje.a113973

14. Franco E, Giambi C, Ialacci R, Coppola RC, Zanetti AR. Risk groups for hepatitis A virus infection. Vaccine. 2003;21(19-20):2224-2233. doi:10.1016/S0264-410X(03)00137-3

15. Koenig KL, Shastry S, Burns MJ. Hepatitis A virus: essential knowledge and a novel identify-isolate-inform tool for frontline healthcare providers. West J Emerg Med. 2017;18(6):1000-1007. doi:10.5811/westjem.2017.10.35983

16. Ryu S, Won SA, Uh J, Song JY. Hepatitis A virus infection from a contaminated tap of ground water facility in a Neighborhood Park, Republic of Korea. Infect Chemother. 2019;51(1):62-66. doi:10.3947/ic.2019.51.1.62

17. Snooks MJ, Bhat P, Mackenzie J, Counihan NA, Vaughan N, Anderson DA. Vectorial entry and release of hepatitis A virus in polarized human hepatocytes. J Virol. 2008;82(17):8733-8742. doi:10.1128/JVI.00219-08

18. Hirai-Yuki A, Hensley L, Whitmire JK, Lemon SM. Biliary secretion of Quasi-enveloped human hepatitis A virus. mBio. 2016;7(6):e01998-16. doi:10.1128/mBio.01998-16

19. Koff RS. Clinical manifestations and diagnosis of hepatitis A virus infection. Vaccine. 1992;10(Suppl 1):S15-S177. doi:10.1016/0264-410X(92) 90533-P

20. Nainan OV, Xia G, Vaughan G, Margolis HS. Diagnosis of hepatitis a virus infection: a molecular approach. Clin Microbiol Rev. 2006;19 (1):63-79. doi:10.1128/CMR.19.1.63-79.2006

21. Walker CM. Adaptive immune responses in hepatitis A virus and hepatitis E virus infections. Cold Spring Harb Perspect Med. 2019;9(9): a033472. doi:10.1101/cshperspect.a033472

22. Dienstag JL, Alling DW, Purcell RH. Quantitation of antibody to hepatitis A antigen by immune electron microscopy. Infect Immun. 1976;13 (4):1209-1213. doi:10.1128/iai.13.4.1209-1213.1976

23. Burkholder BT, Coronado VG, Brown J, et al. Nosocomial transmission of hepatitis A in a pediatric hospital traced to an anti-hepatitis A virus-negative patient with immunodeficiency. Pediatr Infect Dis J. 1995;14(4):261-266. doi:10.1097/00006454-199504000-00003

24. Castrodale L, Fiore A, Schmidt T. Detection of immunoglobulin M antibody to hepatitis A virus in Alaska residents without other evidence of hepatitis. Clin Infect Dis. 2005;41(9):e86-e88. doi:10.1086/497073

25. Young MK, Cripps AW. Passive immunization for the public health control of communicable diseases: current status in four high-income countries and where to next. Hum Vaccin Immunother. 2013;9(9):1885-1893. doi:10.4161/hv.25311

26. Manka P, Verheyen J, Gerken G, Canbay A. Liver failure due to acute viral hepatitis (A-E). Visc Med. 2016;32(2):80-85. doi:10.1159/ 000444915

27. Bravo C, Mege L, Vigne C, Thollot Y. Clinical experience with the inactivated hepatitis A vaccine, avaxim $80 \mathrm{U}$ pediatric. Expert Rev Vaccines. 2019;18(3):209-223. doi:10.1080/14760584.2019.1580578

28. Patient R, Hourioux C, Roingeard P. Morphogenesis of hepatitis B virus and its subviral envelope particles. Cell Microbiol. 2009;11 (11):1561-1570. doi:10.1111/j.1462-5822.2009.01363.x 
29. Shepard CW, Simard EP, Finelli L, Fiore AE, Bell BP. Hepatitis B virus infection: epidemiology and vaccination. Epidemiol Rev. 2006;28:112-125. doi:10.1093/epirev/mxj009

30. Coppola N, Onorato L, Minichini C, et al. Clinical significance of hepatitis B surface antigen mutants. World J Hepatol. 2015;7(27):2729. doi:10.4254/wjh.v7.i27.2729

31. Krajden M, McNabb G, Petric M. The laboratory diagnosis of hepatitis B virus. Can J Infect Dis Med Microbiol. 2005;16(2):65-72. doi: $10.1155 / 2005 / 450574$

32. Maruyama T, Schödel F, Iino S, et al. Distinguishing between acute and symptomatic chronic hepatitis B virus infection. Gastroenterology. 1994;106:1006. doi:10.1016/0016-5085(94)90761-7

33. Terrault NA, Lok ASF, McMahon BJ, et al. Update on prevention, diagnosis, and treatment of chronic hepatitis B: AASLD 2018 hepatitis B guidance. Hepatology. 2018;67:1560. doi:10.1002/hep.29800

34. Cheung WI, Lin SY, Leung VK, et al. Prospective evaluation of seropositive occult hepatitis B viral infection in lymphoma patients receiving chemotherapy. Hong Kong Med J. 2011;17:376-380.

35. Makvandi M. Update on occult hepatitis B virus infection. World J Gastroenterol. 2016;22(39):8720-8734. doi:10.3748/wjg.v22.i39.8720

36. Liang TJ. Hepatitis B: the virus and disease. Hepatology. 2009;49(S5):S13-S21. doi:10.1002/hep.22881

37. Tan A, Koh S, Bertoletti A. Immune response in hepatitis B virus infection. Cold Spring Harb Perspect Med. 2015;5(8):a021428. doi:10.1101/ cshperspect.a021428

38. Croagh CMN, Lubel JS. Natural history of chronic hepatitis B: phases in a complex relationship. World J Gastroenterol. 2014;20 (30):10395-10404. doi:10.3748/wjg.v20.i30.10395

39. Tang L, Covert E, Wilson E, Kottilil S. Chronic hepatitis B infection: a review. JAMA. 2018;319:1802. doi:10.1001/jama.2018.3795

40. Bennett JE, Dolin R, Blaser MJ. Mandell, Douglas, and Bennett's Principles and Practice of Infectious Diseases. Vol. 117. Elsevier Health Sciences; 2019:1548-1582.e9.

41. Zeuzem S, Welsch C, Herrmann E. Pharmacokinetics of peginterferons. Semin Liver Dis. 2003;23(Suppl 1):23-28.

42. Palumbo E. Pegylated interferon and ribavirin treatment for hepatitis C virus infection. Ther Adv Chronic Dis. 2011;2(1):39-45. doi:10.1177/ 2040622310384308

43. Zu Siederdissen CH, Cornberg M. Management of HBV and HBV/HDV-associated liver cirrhosis. Visc Med. 2016;32(2):86-94. doi:10.1159/ 000445518

44. Xie Y-D, Ma H, Feng B, Wei L. Efficacy of real-world entecavir therapy in treatment-naïve chronic hepatitis B patients. Chin Med J. 2017;130 (18):2190-2197. doi:10.4103/0366-6999.213969

45. Casado JL. Renal and bone toxicity with the use of tenofovir: understanding at the end. AIDS Rev. 2016;18(2):59-68.

46. Childs-Kean LM, Egelund EF, Jourjy J. Tenofovir alafenamide for the treatment of chronic hepatitis B monoinfection. Pharmacotherapy. 2018;38(10):1051-1057. doi:10.1002/phar.2174

47. Sarri G, Westby M, Bermingham S, Hill-Cawthorne G, Thomas H. Diagnosis and management of chronic hepatitis B in children, young people, and adults: summary of NICE guidance. BMJ. 2013;26:346.

48. Terrault NA, Bzowej NH, Chang KM, Hwang JP, Jonas MM, Murad MH. A ASLD guidelines for treatment of chronic hepatitis B. Hepatology. 2016;63(1):261-283. doi:10.1002/hep.28156

49. Schillie S, Vellozzi C, Reingold A, et al. Prevention of hepatitis B virus infection in the United States: recommendations of the advisory committee on immunization practices. MMWR Recomm Rep. 2018;67:1. doi:10.15585/mmwr.rr6701a1

50. Keating GM, Noble S. Recombinant hepatitis B vaccine (Engerix-B): a review of its immunogenicity and protective efficacy against hepatitis B. Drugs. 2003;63(10):1021-1051. doi:10.2165/00003495-200363100-00006

51. Van Herck K, Leuridan E, Van Damme P. Schedules for hepatitis B vaccination of risk groups: balancing immunogenicity and compliance. Sex Transm Infect. 2007;83(6):426-432. doi:10.1136/sti.2006.022111

52. Halperin SA, Ward B, Cooper C, et al. Comparison of safety and immunogenicity of two doses of investigational hepatitis B virus surface antigen co-administered with an immunostimulatory phosphorothioate oligodeoxyribonucleotide and three doses of a licensed hepatitis B vaccine in healthy adults 18-55 years of age. Vaccine. 2012;30:2556. doi:10.1016/j.vaccine.2012.01.087

53. Sablan BP, Kim DJ, Barzaga NG, et al. Demonstration of safety and enhanced seroprotection against hepatitis B with investigational HBsAg-1018 ISS vaccine compared to a licensed hepatitis B vaccine. Vaccine. 2012;30:2689. doi:10.1016/j.vaccine.2012.02.001

54. HEPLISAV-B [package insert]. Emeryville, CA: Dynavax Technologies Corporation; 2020. Available from: https://www.fda.gov/downloads/ biologicsbloodvaccines/vaccines/approvedproducts/ucm584762.pdf. Accessed February 28, 2022.

55. Poland GA. Hepatitis B immunization in health care workers. Dealing with vaccine nonresponse. Am J Prev Med. 1998;15:73. doi:10.1016/ s0749-3797(98)00032-4

56. Propst T, Propst A, Lhotta K, Vogel W, König P. Reinforced intradermal hepatitis B vaccination in hemodialysis patients is superior in antibody response to intramuscular or subcutaneous vaccination. Am J Kidney Dis. 1998;32:1041. doi:10.1016/S0272-6386(98)70081-2

57. Jack AD, Hall AJ, Maine N, et al. What level of hepatitis B antibody is protective? J Infect Dis. 1999;179:489. doi:10.1086/314578

58. Peces R, de la Torre M, Alcázar R, Urra JM. Prospective analysis of the factors influencing the antibody response to hepatitis B vaccine in hemodialysis patients. Am J Kidney Dis. 1997;29:239. doi:10.1016/S0272-6386(97)90036-6

59. Bian Y, Zhang Z, Sun Z, et al. Vaccines targeting preS1 domain overcome immune tolerance in hepatitis B virus carrier mice. Hepatology. 2017;66(4):1067-1082. doi:10.1002/hep.29239

60. Shouval D, Roggendorf H, Roggendorf M. Enhanced immune response to hepatitis B vaccination through immunization with a Pre-S1/Pre-S2/S vaccine. Med Microbiol Immunol. 2015;204:57-68. doi:10.1007/s00430-014-0374-x

61. Zhang X, Cheng J, Ma J, et al. Discovery of novel hepatitis B virus nucleocapsid assembly inhibitors. ACS Infect Dis. 2018;5(5):759-768. doi:10.1021/acsinfecdis.8b00269

62. Wu S, Zhao Q, Zhang P, et al. Discovery and mechanistic study of benzamide derivatives that modulate hepatitis B virus capsid assembly. $J$ Virol. 2017;91(16):e00519-17. doi:10.1128/JVI.00519-17

63. Zhu A, Liao X, Li S, et al. HBV cccDNA and its potential as a therapeutic target. J Clin Transl Hepatol. 2019;7(3):258. doi:10.14218/ JCTH.2018.00054 
64. Alter H. Discovery of non-A, non-B hepatitis and identification of its etiology. Am J Med. 1999;107(6b):16s-20s. doi:10.1016/S0002-9343(99) 00375-7

65. Chevaliez S, Pawlotsky JM. HCV genome and life cycle. In: Tan SL, editor. Hepatitis C Viruses: Genomes and Molecular Biology. Norfolk (UK): Horizon Bioscience Copyright (c) 2006, Horizon Bioscience; 2006.

66. Jafri W, Siddiqui B, Awan S. HCV-discovery to elimination, "myth or reality". Hepatoma Res. 2018;4:54. doi:10.20517/2394-5079.2018.36

67. Waheed Y, Siddiq M, Jamil Z, Najmi MH. Hepatitis elimination by 2030: progress and challenges. World J Gastroenterol. 2018;24 (44):4959-4961. doi:10.3748/wjg.v24.i44.4959

68. Taherkhani R, Farshadpour F. Global elimination of hepatitis $\mathrm{C}$ virus infection: progresses and the remaining challenges. World $J$ Hepatol. 2017;9(33):1239-1252. doi:10.4254/wjh.v9.i33.1239

69. TaherKhani R, Farshadpour F. Lurking epidemic of hepatitis C virus infection in Iran: a call to action. World J Hepatol. 2017;9(24):1040-1042. doi:10.4254/wjh.v9.i24.1040

70. Hosseini-Moghaddam SM, Iran-Pour E, Rotstein C, et al. Hepatitis C core Ag and its clinical applicability: potential advantages and disadvantages for diagnosis and follow-up? Rev Med Virol. 2012;22(3):156-165. doi:10.1002/rmv.717

71. Ponnuvel S, Fletcher GJ, Anantharam R, Varughese S, David VG, Abraham P. Clinical utility of hepatitis C virus core antigen (HCVcAg) assay to identify active HCV infection in hemodialysis and renal transplant patients. PLoS One. 2021;16(4):e0250263. doi:10.1371/journal. pone. 0250263

72. Deutsch M, Hadziyannis SJ. Old and emerging therapies in chronic hepatitis C: an update. $J$ Viral Hepat. 2008;15(1):2-11. doi:10.1111/j.13652893.2007.00887.x

73. Stedman C. Sofosbuvir, a NS5B polymerase inhibitor in the treatment of hepatitis C: a review of its clinical potential. Therap Adv Gastroenterol. 2014;7(3):131-140. doi:10.1177/1756283X13515825

74. Hundt J, Li Z, Liu Q. Post-translational modifications of hepatitis C viral proteins and their biological significance. World J Gastroenterol. 2013;19(47):8929-8939. doi:10.3748/wjg.v19.i47.8929

75. Mani N, Yuzhakov A, Yuzhakov O, et al. Nonstructural protein 5A (NS5A) and human replication protein A increase the processivity of hepatitis C virus NS5B polymerase activity in vitro. $J$ Virol. 2015;89(1):165-180. doi:10.1128/JVI.01677-14

76. Gouklani H, Bull RA, Beyer C, et al. Hepatitis C virus nonstructural protein 5B is involved in virus morphogenesis. $J$ Virol. $2012 ; 86$ (9):5080-5088. doi:10.1128/JVI.07089-11

77. Meewan I, Zhang X, Roy S, et al. Discovery of new inhibitors of hepatitis C virus NS3/4A protease and its D168A mutant. ACS Omega. 2019;4 (16):16999-17008. doi:10.1021/acsomega.9b02491

78. Singh A, Kumari S, Kumar P, De A, Singh V. Sofosbuvir with NS5A inhibitors in hepatitis C virus infection with severe renal insufficiency. $J$ Viral Hepatitis. 2018;25(12):1501-1506. doi:10.1111/jvh.12983

79. Hézode C. Pan-genotypic treatment regimens for hepatitis C virus: advantages and disadvantages in high- and low-income regions. $J$ Viral Hepat. 2017;24(2):92-101. doi:10.1111/jvh.12635

80. Rizzetto M. Hepatitis D virus: introduction and epidemiology. Cold Spring Harb Perspect Med. 2015;5(7):a021576. doi:10.1101/cshperspect. a021576

81. Steger G, Riesner D. Viroid research and its significance for RNA technology and basic biochemistry. Nucleic Acids Res. 2018;46 (20):10563-10576. doi:10.1093/nar/gky903

82. Miao Z, Zhang S, Ou X, et al. Estimating the global prevalence, disease progression, and clinical outcome of hepatitis delta virus infection. $J$ Infect Dis. 2020;221(10):1677-1687. doi:10.1093/infdis/jiz633

83. Farci P, Anna Niro G. Current and future management of chronic hepatitis D. Gastroenterol Hepatol. 2018;14(6):342-351.

84. Butt N, Khan M, Haleem F. Acute viral hepatitis: simultaneous infection from hepatitis A, B and E viruses. J Coll Physicians Surg Pak. 2019;29:S103-S5. doi:10.29271/jcpsp.2019.12.S103

85. Myers RP, Ratziu V, Benhamou Y, et al. Infections with multiple hepatotropic viruses. Polymicrob Dis. 2002:51-73. doi:10.1128/ 9781555817947.ch4

86. Masood U, John S. Hepatitis D. StatPearls. Treasure Island, FL: StatPearls Publishing Copyright (C) 2020, StatPearls Publishing LLC; 2020.

87. Le Gal F, Gordien E, Affolabi D, et al. Quantification of hepatitis delta virus RNA in serum by consensus real-time PCR indicates different patterns of virological response to interferon therapy in chronically infected patients. J Clin Microbiol. 2005;43(5):2363-2369. doi:10.1128/ JCM.43.5.2363-2369.2005

88. Negro F. Hepatitis D virus coinfection and superinfection. Cold Spring Harb Perspect Med. 2014;4(11):a021550. doi:10.1101/cshperspect. a021550

89. Heidrich B, Yurdaydın C, Kabaçam G, et al. Late HDV RNA relapse after peginterferon alpha-based therapy of chronic hepatitis delta Hepatology. 2014;60(1):87-97. doi:10.1002/hep.27102

90. Watashi K, Wakita T. Hepatitis B virus and hepatitis D virus entry, species specificity, and tissue tropism. Cold Spring Harb Perspect Med. 2015;5(8):a021378-a. doi:10.1101/cshperspect.a021378

91. Koh C, Canini L, Dahari H, et al. Oral prenylation inhibition with lonafarnib in chronic hepatitis D infection: a proof-of-concept randomised, double-blind, placebo-controlled phase 2A trial. Lancet Infect Dis. 2015;15(10):1167-1174. doi:10.1016/S1473-3099(15)00074-2

92. Loglio A, Segato S. Hepatitis D - how is the fight against this foe going? Expert Rev Clin Pharmacol. 2019;12(3):169-171. doi:10.1080/ 17512433.2019.1577135

93. Deterding K, Wedemeyer H. Beyond pegylated interferon-alpha: new treatments for hepatitis delta. AIDS Rev. 2019;21(3):126-134. doi:10.24875/AIDSRev.19000080

94. Reyes GR, Purdy MA, Kim JP, et al. Isolation of a cDNA from the virus responsible for enterically transmitted non-A, non-B hepatitis. Science. 1990;247(4948):1335-1339. doi: 10.1126/science.2107574.

95. LeDesma R, Nimgaonkar I, Ploss A. Hepatitis E virus replication. Viruses. 2019;11(8):719. doi:10.3390/v11080719

96. Murrison LB, Sherman KE. The enigma of hepatitis E virus. Gastroenterol Hepatol. 2017;13(8):484-491.

97. Farshadpour F, Taherkhani S, Taherkhani R. Hepatitis E virus infection during pregnancy: the overlooked cause of maternal and fetal mortality. Infect Disord Drug Targets. 2019;19(3):334-336. doi:10.2174/1871526518666180530075523

98. Acharya SK. Hepatitis E and acute liver failure in pregnancy. J Clin Exp Hepatol. 2013;3(3):213-224. doi:10.1016/j.jceh.2013.08.009 
99. Taherkhani R, Farshadpour F. Epidemiology of hepatitis E in pregnant women and children in Iran: a general overview. J Clin Transl Hepatol. 2016;4(3):269-276. doi:10.14218/JCTH.2016.00013

100. Kamar N, Dalton HR, Abravanel F, Izopet J. Hepatitis E virus infection. Clin Microbiol Rev. 2014;27(1):116-138. doi:10.1128/CMR.00057-13

101. Borkakoti J, Ahmed G, Rai A, Kar P. Report of novel H105R, D29N, V27A mutations in the methyltransferase region of the HEV genome in patients with acute liver failure. J Clin Virol. 2017;91:1-4. doi:10.1016/j.jcv.2017.03.017

102. Lin CC, Wu JC, Chang TT, et al. Diagnostic value of immunoglobulin G (IgG) and IgM anti-hepatitis E virus (HEV) tests based on HEV RNA in an area where hepatitis E is not endemic. J Clin Microbiol. 2000;38(11):3915-3918. doi:10.1128/JCM.38.11.3915-3918.2000

103. Abbas Z, Afzal R. Hepatitis E: when to treat and how to treat. Antivir Ther. 2013;19(2):125-131. doi:10.3851/IMP2705

104. Dao Thi VL, Debing Y, Wu X, et al. Sofosbuvir inhibits hepatitis E virus replication in vitro and results in an additive effect when combined with ribavirin. Gastroenterology. 2016;150(1):82-5.e4. doi:10.1053/j.gastro.2015.09.011

105. Wu X, Chen P, Lin H, Hao X, Liang Z. Hepatitis E virus: current epidemiology and vaccine. Hum Vaccin Immunother. 2016;12(10):2603-2610. doi:10.1080/21645515.2016.1184806

106. Lesmanawati DAS, Adam DC, Hooshmand E, Moa A, Kunasekaran MP, MacIntyre CR. The global epidemiology of hepatitis A outbreaks 2016-2018 and the utility of EpiWATCH as a rapid epidemic intelligence service. Global Biosecurity. 2021;3(1). doi:10.31646/gbio.100

107. Kumar V, Abbas AK, Aster JC. Robbins and Cotran Pathologic Basis of Disease. 9th ed. Philadelphia, PA: Elsevier/Saunders; 2015.

\section{Publish your work in this journal}

Hepatic Medicine: Evidence and Research is an international, peer-reviewed, open access journal covering all aspects of adult and pediatric hepatology in the clinic and laboratory including the following topics: Pathology, pathophysiology of hepatic disease; Investigation and treatment of hepatic disease; Pharmacology of drugs used for the treatment of hepatic disease. Issues of patient safety and quality of care will also be considered. The manuscript management system is completely online and includes a very quick and fair peer-review system, which is all easy to use. Visit http://www.dovepress.com/testimonials.php to read real quotes from published authors.

Submit your manuscript here: https://www.dovepress.com/hepatic-medicine-evidence-and-research-journal 